\title{
Antioxidative and Antimicrobial Screening of 19 Commercial Essential Oils in Turkey
}

Ç. Bulut, E. Altiok, O. Bayraktar and S. Ülkü

Izmir Institute of Technology, Department of Chemical Engineering

35430 Urla, İzmir

Turkey

Keywords: antioxidant capacity, antimicrobial property, essential oil

\begin{abstract}
Plant oils have been used for wide variety purposes for many years in Turkey. These essential oils have usage in many areas such as perfumery, cosmetic, food flavoring and folkloric medicine. In the study, 19 commercial essential oils were studied by means of antibacterial and antioxidant capacity. Antibacterial test was performed against $S$. aureus, $S$. epidermidis, $K$. pneumoniae and $E$. coli using standard disc diffusion method. Penicillin, gentamicin and vancomycin discs were also included. Inhibition zones $(\mathrm{mm})$ were recorded to indicate antibacterial property. Penicillin $(44 \mathrm{~mm})$ and vancomycin $(14 \mathrm{~mm})$ could inhibit only $S$. aureus. Except essential oils of Juniperus nana (Ardıç), Ocimum basilicum (Fesleğen), Urtica dioica (IsIrgan), Foeniculum vulgare (Rezene) remaining essential oils indicated antimicrobial activity against some of the test microorganims. The most active essential oil was found as Thymus serpyllum (Kekik). It indicated highest inhibition zones for other microorganisms among others. Antioxidant capacities were measured using photochemiluminescence (PCL) method. The highest antioxidant activity was measured for Dianthus caryophyllus (Karanfil) as $547.7811^{3} \mu \mathrm{g}$ trolox/mL of oil. It was followed by Thymus serpyllum (Kekik), Lilium candidum (Zambak) and Matricaria chamomilla (Papatya). Especially, Thymus serpyllum and Dianthus caryophyllus have significant antimicrobial and antioxidant capacity therefore it could be suggested for further investigations and applications.
\end{abstract}

\section{INTRODUCTION}

It is known that Turkish flora comprises 9300 plant species (Taşdemier et al., 2004). This fact highlighted the diversity of the plant essential oils. Essential oils and their components are gaining increasing interest because of their relatively safe status, their wide acceptance by consumers, and their exploitation for potential multi-purpose functional use. Various industries demand to sources of alternative, more natural and environmentally friendly antimicrobials, antibiotics, antioxidants and crop protection agents. A major problem in antimicrobial chemotherapy is the increasing occurrence of resistance to antibiotics, which leads to the insufficiency of antimicrobial treatment. Therefore, the use of essential oils as functional ingredients in foods, drinks, toiletries and cosmetics has been increased recently.

Recent studies on antioxidant and antimicrobial properties of some of the essential oils were tabulated (Table 1).

The objective of this work is to compare the antioxidant and antimicrobial properties of 19 common commercial oils in Turkey.

\section{MATERIALS AND METHODS}

\section{Microorganisms and Growth Condition}

Reference strains of Staphylococcus aureus, Klebsiella pneumoniae, Escherichia coli and Staphylococcus epidermidis were provided by the Biology Department of İzmir Institute of Technology (IYTE). The frozen glycerol stocks were activated in Mueller Hinton Broths at $37^{\circ} \mathrm{C}$ for overnight by using shaker incubator. Then, they were streaked on Mueller Hinton agar medium and incubated $37^{\circ} \mathrm{C}$ for overnight. 


\section{Commercial Essential Oils}

19 of commercial plant oil in $25 \mathrm{ml}$ packed bottles were obtained by market. These are Salvia officinalis, Ocimum basilicum, Citrus bergamia, Rosmarinus officinalis, Laurus nobilis, Thymus serpyllum, Urtica dioica, Lavandula stoechas, Dianthus caryophyllus, Juniperus nana, Melissa officinalis, Viola tricolor, Myrtus communis, Mentha piperita, Matricaria chamomilla, Vitex agnus-castus, Jasminum officinal, Lilium candidum, Foeniculum vulgare.

\section{Screening for Antimicrobial Activities}

$5 \mathrm{ml}$ of essential oils were sterilized by filtration through a $0.45 \mu \mathrm{m}$ membrane filter into sterile falcon tubes. Antimicrobial tests were then performed by the disc diffusion method (Murray et al., 1995). From overnight cultures of test microorganisms, approximately, 5 colonies were picked up by using sterile cotton swabs and dissolved in $2.5 \mathrm{ml}$ Phosphate-buffered saline (PBS) solution and turbidity was adjusted to McFarland 0.5 . Then, the swab was streaked on the Mueller Hinton agar plates. The sterile discs with $6 \mathrm{~mm}$ diameter were impregnated with essential oil and placed on the inoculated agar. Each plate was divided 4 equal parts and 4 essential oil discs were placed on it. Then, plates were incubated at $37^{\circ} \mathrm{C}$ for $24 \mathrm{~h}$. All the tests performed in duplicate. The clear zones around the discs were measured and recorded as inhibition zone that indicate antimicrobial property. Antibiotic discs (Penicillin, gentamicin and vancomycin) were also included in antimicrobial assay.

\section{Measurement of Antioxidant Capacity}

The luminol-photochemiluminescence assay was carried out with the procedure described by the manufacturer. PCL detection method using a Photochem (Analytik Jena AG, Jena, Germany) system was used to measure lipid soluble (ACL) antioxidant capacities. PCL is the most suitable method since it is used to measure the superoxide radical, which is the free radical generated also by human body (Schlesier et al., 2002). For this purpose, samples were diluted with methanol and the antioxidant activity was measured using "ACL" kit provided, and the procedures were followed as described by the manufacturer. Appropriate dilutions were made by methanol in order to detect antioxidative inhibition of luminol. The antioxidant capacity (ACL) of a sample was expressed in equivalent concentrations of the standard compounds of trolox.

\section{RESULTS AND DISCUSSION}

Antimicrobial activity of 19 essential oil samples was evaluated in vitro against four bacterial species (Table 2). The agar diffusion method gave semiquantitative data about the antimicrobial activities of the essential oils. The inhibitory zones indicated that the most effective oil is thyme oil; the zones of inhibition were the largest both for the four bacteria. Therefore, Thymus sepyllum could be considered as a rich source of antimicrobial agents and it could serve as a source for compounds with therapeutic potential.

Some of the essential oils did not indicate any antimicrobial activity against the test microorganisms. These are Juniperus nana (Ardıç), Ocimum basilicum (Fesleğen), Urtica dioica (Isirgan), Foeniculum vulgare (Rezene).

Among the test microorganisms it was found that Klebsiella was least susceptible to the essential oils. The most narrow inhibition zones with no inhibitions were observed for this microorganism.

The results highlighted that especially 4 essential oils as namely Thymus sepyllum (Kekik), Matricaria chamomilla (Papatya), Lilium candidum (Zambak) and Dianthus caryophyllus (Karanfil) have significant antimicrobial potential within the 19 commercial oil samples. This evidence should also be evaluated in various application areas. Differences in antimicrobial properties could be explained in differences in their contents of active compounds. The antimicrobial properties of thyme essential oils are mainly related to their high phenolic content. It was reported that carvacrol and thymol was found 
the most efficient against both reference strains and food-derived bacteria. Additionally, phenolic type essential oils, containing thymol and carvacrol as major components were reported to exhibit strong antioxidant activity (Cosentino et al., 1999). There could be relation between antimicrobial property and antioxidant capacity of the essential oil.

Antioxidant results indicated that Dianthus caryophyllus has the greatest antioxidant activity (Table 3 ). Antioxidant activities of essential oils from aromatic plants are mainly attributed to the active compounds present. Eugenol was reported as responsible active compound for antioxidant activity of this essential oil (Politeo et al., 2006).

\section{CONCLUSION}

All the tested oils were also investigated for their antimicrobial and antioxidant activities to highlight possible applications. In particular, PCL assay that measures the ability, of a given substance or mixture, to quench $\mathrm{O}_{2}{ }^{-}$, one of the most dangerous reactive oxygen species (ROS) for human health was performed. The PCL method is based on the photo-induced autoxidation inhibition of luminol by antioxidants mediated from the radical anion superoxide $\mathrm{O}_{2}^{-}$. This is a deleterious by-product of oxygen metabolism that responsible for the most important damage related to reperfusion injuries. Therefore, the values obtained by the PCL method directly relate to health properties of a given ingredient. The PCL assay, conducted under the ACL protocol, is particularly suitable for determining the radical-scavenging activity of lipid-soluble antioxidants such as essential oils. It was reported that data obtained from PCL testing were consistent with those obtained in the other antioxidant analyzing methods of 1,1-diphenyl-2picrylhydrazyl (DPPH) assay and $\beta$-carotene bleaching test (Sacchett et al., 2005).

Comparison of the antimicrobial data with previously published results could be difficult. (Hammer et al., 1999). First, the composition of plant oils and extracts is known to vary according to local climatic and environmental conditions (Janssen et al., 1987; Sivropoulou et al., 1995). Furthermore, some oils with the same common name may be derived from different plant species. Second, the method used to assess antimicrobial activity, and the choice of test organisms varies (Janssen et al., 1987).

In conclusion, this study suggest that especially four essential oil Thymus sepyllum Matricaria chamomilla, Lilium candidum and Dianthus caryophyllus have noticeable antimicrobial and antioxidative potential. These essential oils and active components may find new usage areas in different industries.

\section{Literature Cited}

Cosentino, S., Tuberoso, C.I.G., Pisano, B., Satta, M., Mascia, V., Arzedi, E. and Palmas, F. 1999. In-vitro antimicrobial activity and chemical composition of Sardinian Thymus essential oils. Letters in Applied Microbiology 29: 130-135.

Dunan, F., Marián, S., Katarína, D. and Dobroslava, B. 2006. Essential oils-their antimicrobial activity against Escherichia coli and effect on intestinal cell viability. Toxicology in Vitro 20: 1435-1445.

Gachkar, L., Yadegari, D., Rezaei, M.B., Taghizadeh, M., Astaneh, S.A. and Rasooli, I. 2007. Chemical and biological characteristics of Cuminum cyminum and Rosmarinus officinalis essential oils Food Chemistry 102:898-904.

Hammer, K.A., Carson, C.F and Riley, T. V.1999. Antimicrobial activity of essential oils and other plant extracts Journal of Applied Microbiology 86: 985-990.

Janssen, A.M., Scheffer, J.J.C. and Baerheim Svendsen, A. 1987. Antimicrobial activity of essential oils: a 1976-86 literature review. Aspects of the test methods. Planta Medica 53: 395-398.

Lee, S.J., Umano, K., Takayuki Shibamoto, T. and Lee, K.G. 2005. Identification of volatile components in basil (Ocimum basilicum L.) and thyme leaves (Thymus vulgaris L.) and their antioxidant properties. Food Chemistry 91:131-137.

Murray, P.R., Baron, E.J., Pfaller, M.A., Tenover, F.C. and Yolke, R.H. 1995. Manual of Clinical Microbiology, vol. 6th ed. ASM, Washington, DC. 
Politeo,O., Juki, M. and Milo, M. 2006. Chemical Composition and Antioxidant Activity of Essential Oils of Twelve Spice Plants. Croatica Chemica Acta (79):545-552.

Sacchetti, G., Maietti, S., Muzzoli, M., Scaglianti, M., Manfredini, S. Radice, M. and Bruni, R. 2005.Comparative evaluation of 11 essential oils of different origin as functional antioxidants, antiradicals and antimicrobials in foods. Food Chemistry 91: 621-632.

Tasdemir, D., Dönmez, A.A., Çalıs, I. and Rüedi, P. 2004. Evaluation of Biological Activity of Turkish Plants. Rapid Screening for the Antimicrobial, Antioxidant, and Acetylcholinesterase Inhibitory Potential by TLC Bioautographic Methods Pharmaceutical Biology 42:374-383.

Schlesier, K., Harwat, M., Böhm, V. and Bitsch, R. 2002. Assessment of antioxidant activity by using different in vitro methods. Free Radical Research 36:177-187.

Schelz, Z., Molnar, J. and Hohmann, J. 2006. Antimicrobial and antiplasmid activities of essential oils. Fitoterapia 77:279-285.

Sivropoulou, A., Kokkini, S., Lanaras, T. and Arsenakis, M. 1995. Antimicrobial activity of mint essential oils. Journal of Agricultural and Food Chemistry 43:2384-2388.

Yadegarinia, D., Gachkar, L., Rezaei, M.B., Taghizadeh, M., Shakiba Alipoor Astaneh, S. A. and Rasooli, I. 2006.Biochemical activities of Iranian Mentha piperita L. and Myrtus communis L. essential oils. Phytochemistry 67:1249-1255. 


\section{$\underline{\text { Tables }}$}

Table 1. Recent literature review on some of the essential oils.

\begin{tabular}{|c|c|c|}
\hline Essential oil & Results & Rerefence \\
\hline $\begin{array}{l}\text { Ocimum basilicum, } \\
\text { Thymus vulgaris }\end{array}$ & $\begin{array}{l}\text { Twelve aroma constituents of basil and thyme } \\
\text { were examined for their antioxidant activities. } \\
\text { Eugenol, thymol, carvacrol, and 4-allylphenol } \\
\text { showed stronger antioxidant activities than did the } \\
\text { other components tested in the assay. }\end{array}$ & Lee et al., 2005 \\
\hline Thyme oil, Clove oil & $\begin{array}{l}\text { Antimicrobial activity of selected plant extracts } \\
\text { against enteroinvasive } E \text {. coli was dose } \\
\text { dependent. The addition of low, medium and the } \\
\text { majority of high doses of essential oils and their } \\
\text { components into bacterial suspension had no } \\
\text { evident effect on the viability of enteroinvasive } E \text {. } \\
\text { coli after } 1 \mathrm{~h} \text { incubation. After } 24 \mathrm{~h} \text { incubation, } \\
\text { satisfactory antimicrobial effect was recorded in } \\
\text { all essential oil groups. }\end{array}$ & $\begin{array}{l}\text { Dusan et al., } \\
2006\end{array}$ \\
\hline $\begin{array}{l}\text { Mentha piperita, } \\
\text { Myrtus communis }\end{array}$ & $\begin{array}{l}\text { The oils had good to excellent antimicrobial } \\
\text { activities against } E \text {. coli, } S \text {. aureus and } C \text {. } \\
\text { albicans with the oil of } M \text {. piperita being more } \\
\text { active. They were screened for their possible } \\
\text { antioxidant activities by two complementary test } \\
\text { systems, namely DPPH free radical scavenging } \\
\text { and b-carotene/linoleic acid systems. M. piperirta } \\
\text { oil exerted greater antioxidant activity than that of } \\
\text { M. communis }\end{array}$ & $\begin{array}{l}\text { Yadegarinia } \\
\text { et al., } 2006\end{array}$ \\
\hline $\begin{array}{l}\text { Foeniculum vulgare, } \\
\text { Mentha piperita, } \\
\text { Rosmarinus } \\
\text { officinalis, Thymus } \\
\text { vulgaris }\end{array}$ & $\begin{array}{l}\text { Thymus vulgaris indicated lowest minimum } \\
\text { inhibition concentrations (MICs) for the bacteria. } \\
\text { Rosemary oil displayed the weakest } \\
\text { effect against the bacteria. }\end{array}$ & $\begin{array}{l}\text { Schelz } \\
\text { et al., } 2006\end{array}$ \\
\hline $\begin{array}{l}\text { Syzygium aromaticum } \\
\text { L., Ocimum } \\
\text { basilicum, Laurus } \\
\text { nobilis L., Mentha } \\
\text { piperita L., Salvia } \\
\text { officinalis L., } \\
\text { Foeniculum vulgare }\end{array}$ & $\begin{array}{l}\text { Essential oils from three spice plants, i.e., clove, } \\
\text { basil and laurel, could be used as a potential } \\
\text { source of natural antioxidants. The antioxidant } \\
\text { activity of clove essential oil is mainly due to the } \\
\text { high content of eugenol. }\end{array}$ & $\begin{array}{l}\text { Politeo et al., } \\
2006\end{array}$ \\
\hline $\begin{array}{l}\text { Cuminum cyminum, } \\
\text { Rosmarinus officinalis }\end{array}$ & $\begin{array}{l}\text { C. cyminum oil exhibited stronger antimicrobial } \\
\text { activity than did } R \text {. officinalis oil against } E \text {. coli, } \\
S \text {. aureus and } L \text {. monocytogenes. The radical } \\
\text { scavenging performance of the rosemary oil was } \\
\text { better than that of } C \text {. cyminum. }\end{array}$ & $\begin{array}{l}\text { Gachkar et al., } \\
2007\end{array}$ \\
\hline
\end{tabular}


Table 2. Antimicrobial results of essential oils.

\begin{tabular}{llcccc}
\hline \multicolumn{5}{c}{ Inhibition zone diameter (mm) } \\
\hline & Microrganisms & E.coli & Klebsiella & S. aureus & S. epidermidis \\
\cline { 2 - 6 } No & Essential oil & 10 & - & 9 & 13 \\
\hline 1 & Salvia officinalis & - & - & - & - \\
2 & Juniperus nana & 8 & - & 9 & 11 \\
3 & Citrus bergamia & 9,5 & - & - & - \\
4 & Rosmarinus officinalis & 9 & - & 8 & 13 \\
5 & Laurus nobilis & - & - & - & - \\
6 & Ocimum basilicum & - & - & - & - \\
7 & Urtica dioica & 11 & 8 & 11,5 & 11,5 \\
8 & Lavandula stoechas & 18 & 13,5 & 14 & 15 \\
9 & Dianthus caryophyllus & 31,5 & 17,5 & 26 & 26 \\
10 & Thymus serpyllum & 10 & - & 10 & 12 \\
11 & Melissa officinalis & 11,5 & 12 & 8,5 & 12 \\
12 & Viola tricolor & - & - & 9 & 11 \\
13 & Myrtus communis & 13,5 & 9 & 10 & 9 \\
14 & Mentha piperita & 16 & 14 & 17 & 15 \\
15 & Matricaria chamomilla & - & - & - & - \\
16 & Foeniculum vulgare & 10,5 & 15 & 10 & - \\
17 & Jasminum Officinale & 12 & 16 & 15 & 19 \\
18 & Lilium candidum & - & - & 10,5 & - \\
19 & Vitex agnus-castus & & & & \\
\hline
\end{tabular}

${ }^{a}$ Disc diameter, $6 \mathrm{~mm}$; -, No inhibition observed

Table 3. Antioxidant potentials of essential oils.

\begin{tabular}{llc}
\hline No & Essential oil & $\begin{array}{c}\text { Trolox equivalent antioxidant } \\
\text { capacity }(\mu \mathrm{g} / \mathrm{ml} \text { oil })\end{array}$ \\
\hline 1 & Dianthus caryophyllus & 541211,2 \\
2 & Thymus serpyllum & 231000 \\
3 & Lilium candidum & 55341,33 \\
4 & Matricaria chamomilla & 49246,525 \\
5 & Myrtus communis & 26894,735 \\
6 & Laurus nobilis & 24441,795 \\
7 & Vitex agnus-castus & 21926,28 \\
8 & Lavandula stoechas & 18340,73 \\
9 & Salvia officinalis & 13253,385 \\
10 & Rosmarinus officinalis & 11739,07 \\
11 & Foeniculum vulgare & 9110,92 \\
12 & Citrus bergamia & 8910,68 \\
13 & Mentha piperita & 8635,35 \\
14 & Viola tricolor & 8360,02 \\
15 & Urtica dioica & 7271,215 \\
16 & Juniperus nana & 7027,17 \\
17 & Ocimum basilicum & 6144,865 \\
18 & Melissa officinalis & 5406,48 \\
\hline
\end{tabular}

